\title{
Scientific Drilling with the Sea Floor Drill Rig MeBo
}

\author{
by Tim Freudenthal and Gerold Wefer
}

doi:10.2204/iodp.sd.5.11.2007

\section{Introduction}

In March 2007 the sea floor drill rig MeBo (short for "Meeresboden-Bohrgerät", 'sea floor drill rig' in German) returned from a 17-day scientific cruise with the new German research vessel Maria S. Merian. Four sites between $350 \mathrm{~m}$ and $1700 \mathrm{~m}$ water depth were sampled at the continental slope off Morocco by push coring and rotary drilling. Up to 41.5-m-long sediment cores were recovered from Miocene, Pliocene, and Pleistocene marls. MeBo bridges the gap between conventional sampling methods from standard multipurpose research vessels (gravity corer, piston corer, dredges) and drill ships. Most bigger research vessels will be able to support deployment of the MeBo. Since the drill system can be easily transported within 20 -ft containers, worldwide operation from vessels of opportunity is possible. With the MeBo a new system is available for marine geosciences that allows the recovery of high quality samples from soft sediments and hard rock from the deep sea without relying on the services of expensive drilling vessels.

\section{Rationale}

A variety of research targets in marine sciences-including gas hydrates, mud mounds and mud volcanoes, ore formation, and paleoclimate-can be addressed by shallow drilling (30-100 $\mathrm{m}$ below sea floor) in the deep sea (Quinn and Mountain, 2000; Sager et al., 2003; Herzig et al., 2003). In general, standard sampling tools like gravity corers or dredges only allow recovery of fairly short cores from soft sediments or fragments of bedrock lying on the sea surface. Drill ships providing deeper penetration are expensive and typically booked far in advance, if available at all; therefore at the Marum Center for Marine Environmental Sciences (Marum) at the University of Bremen we developed the drill rig MeBo (Freudenthal and Wefer, 2006) that can be deployed from standard research vessels.

\section{System Concept}

The MeBo is deployed on the sea bed and is remotely controlled from the vessel (Fig.1). The rig is lowered to the sea bed using a steel- armored umbilical with a diameter of $32 \mathrm{~mm}$. The deployment depth is currently limited to a maximum of $2000 \mathrm{~m}$ below sea level by the length and strength of the umbilical. Four legs are extended before landing to increase the stability of the rig (Fig. 2). Copper wires and fiber optic cables within the umbilical are used for energy supply from the vessel and for communication between the MeBo and the control unit on the deck of the vessel, respectively. The drill rig is powered by four hydraulic pumps that are driven with electric motors. A variety of sensors, video cameras, and lights are used for monitoring the drill performance.

The mast with the feeding system forms the central part of the drill rig (Fig. 2). The drill head provides the required torque and rotary speed for rock drilling; it is mounted on a guide carriage that moves up and down the mast with a maximum push force of 4 tons. A water pump provides sea water for flushing the drill string, for cooling of the drill bit, and for removing the drill cuttings. The system utilizes commercial rotary core barrels with diamond or tungsten carbide bits. In addition it can push core barrels into soft formations, and case the boreholes.

The MeBo stores drilling rods, casing tubes, and pushcoring and rotary barrels on two rotating magazines that

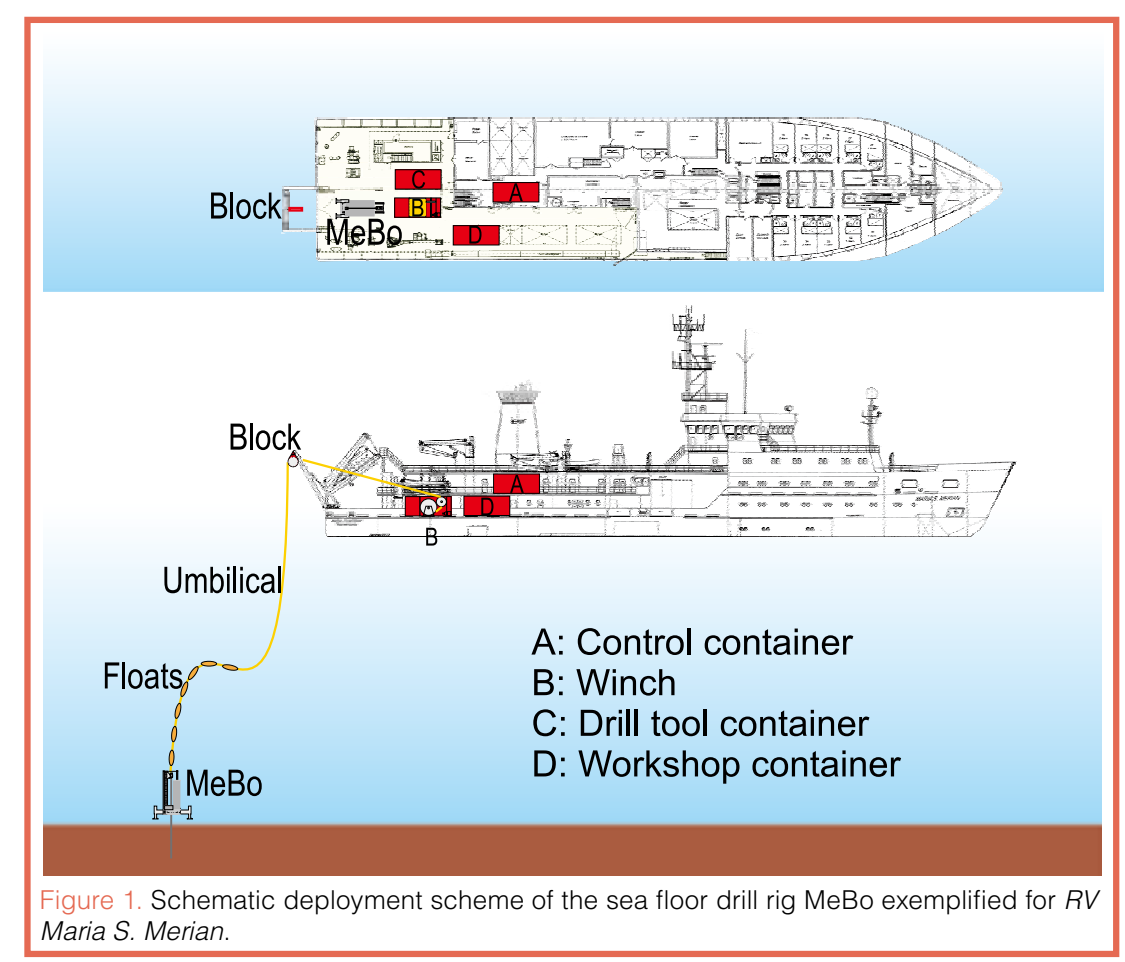




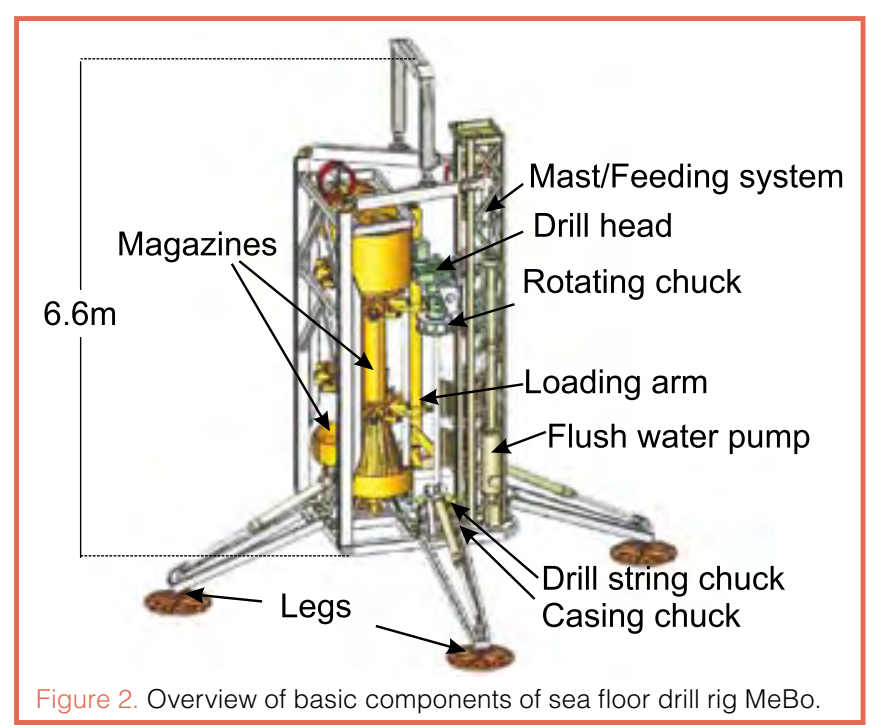

may be loaded with a mixture of tools as required for a specific task. The loading arm is used in combination with one rotating and two fixed chucks for building the drill string up and down. When drilling is started, a core barrel is taken off the magazine and loaded below the drill head. After the thread connection between barrel head and drill head is closed, the first three meters can be sampled. The barrel is then stored together with the drilled core in the magazine, and the next empty core barrel is lowered into the drilled hole. A 3-m rod is added, and the next three meters can be sampled. With a storing capacity of 17 barrels, 16 rods and 15 casing tubes, the MeBo has the capability to drill up to $50 \mathrm{~m}$ into the sea floor, to recover cores with 74-84 mm diameter, and to stabilize the drilled hole down to a depth of $40 \mathrm{~m}$.

Easy transportation was a key requirement for the system design, since the MeBo is deployed worldwide from vessels of opportunity (Fig. 3). All parts belonging to the MeBo system, including control unit, workshop, a rack for the drill tools, and the winch, are containerized (Fig. 3). The MeBo unit fits into an open top high cube 20 -ft container when the four legs are retracted. In addition, a launch and recovery system that was developed for the deployment of the MeBo from the German research vessel Meteor can be adapted to the deck configuration of other vessels. It, too, fits into a $20-\mathrm{ft}$ open top container when dismantled. Altogether, the complete MeBo system is shipped within six 20-ft containers.

\section{Development and Tests}

Previous developments of sea bed drill rigs proved the advantages of drilling from a stable platform at the sea floor but demonstrated also the challenges of remotely controlled drilling and drill string handling (Johnson, 1991; Stuart, 2004). Only a few prototype systems of sea bed drill rigs, including the Rockdrill from the British Geological Survey, the Japanese BMS, and the Australian PROD (Portable Remotely Operated Drill), are operated worldwide, with only the PROD system capable of reaching drilling depths of more than $30 \mathrm{~m}$. Since this system is dedicated to operations in the marine geotechnical survey industry (Stuart, 2004), we decided to establish a new development—the sea floor drill rig MeBo-optimized for the requirements and facilities for scientific investigations of the sea floor.

The development was realized at the Marum with support from a variety of national and international companies. Next to overall system design, project management, and system integration, the Marum Center was responsible for the sensors as well as control hardware and software of the system. Most of the mechanical and hydraulic parts of the drill rig were developed, manufactured, and assembled by Prakla Bohrtechnik GmbH (Peine, Germany), a company specializing in the fabrication of multi-purpose land drill rigs for core drilling and well installation. The energy supply and telemetry system were designed and delivered by Schilling Robotics (Davis, California), Hogenkamp (Lilienthal, Germany), and STA GmbH (Bremerhaven, Germany). Schilling Robotics also developed the rotating magazines and the loading arm. The umbilical was designed and manufactured by Norddeutsche Seekabelwerke (Nordenham, Germany), while the winch was delivered by MacArtney (Esbjerg, Denmark).

After an engineering and construction phase of about one year, the system was tested successfully in July/August 2005 in deep water at the continental slope off Morocco with the German research vessel Meteor (Wefer et al., 2006). Within the following year, two further expeditions were conducted with the Irish research vessel Celtic Explorer: one for shallow

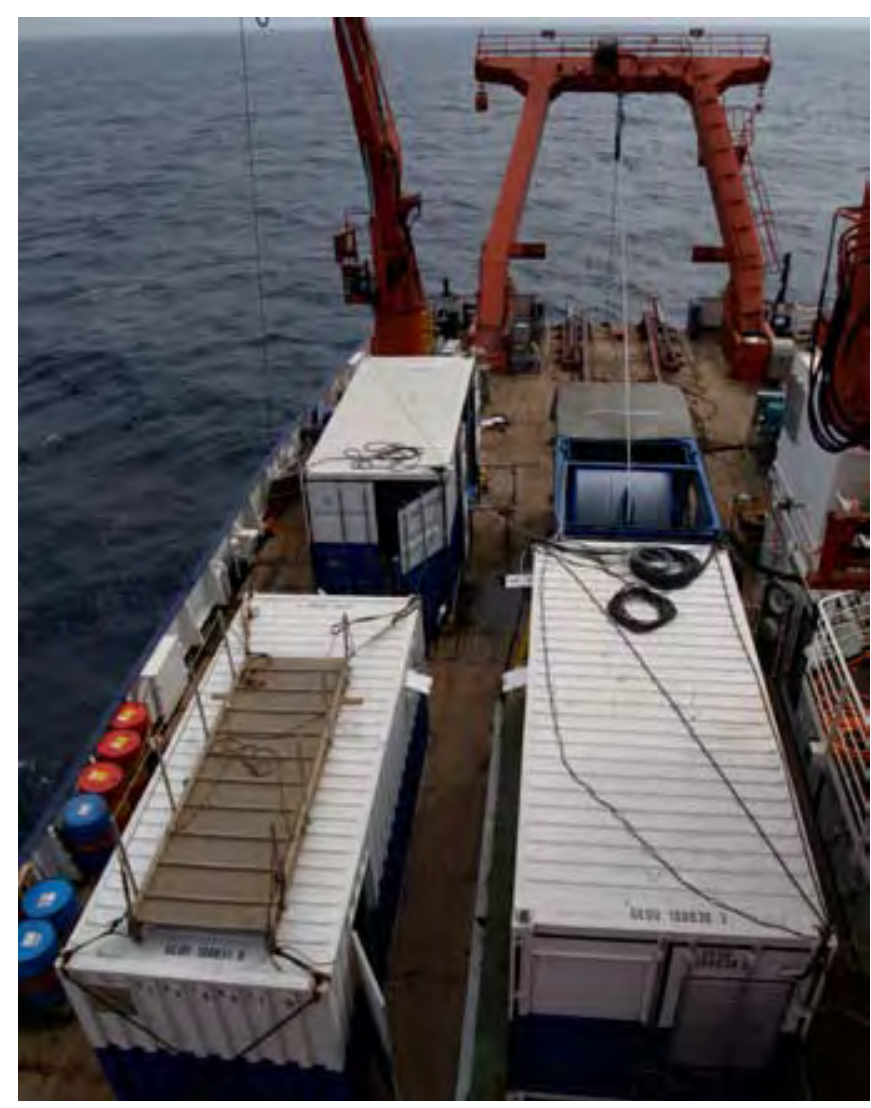

Figure 3. View of the work deck of RV Meteor during a deployment of the sea floor drill rig MeBo. 
water tests of the MeBo system in the Baltic Sea, and a first scientific cruise on the Porcupine Bank west of Ireland for the Irish Shelf Petrol Studies Group (ISPSG) of the Irish Petroleum Infrastructure Programme Group 4.

During these two cruises, the MeBo was deployed twenty times between $20 \mathrm{~m}$ and $1700 \mathrm{~m}$. Push coring for soft sediments and rotary drilling for hard rocks, as well as stabilization of the drilled hole by setting casings, were successfully accomplished. Altogether, 127 meters were drilled in sand, gravel, marl, till, conglomerates, breccia, granite, and gneiss, and 57.2 meters of

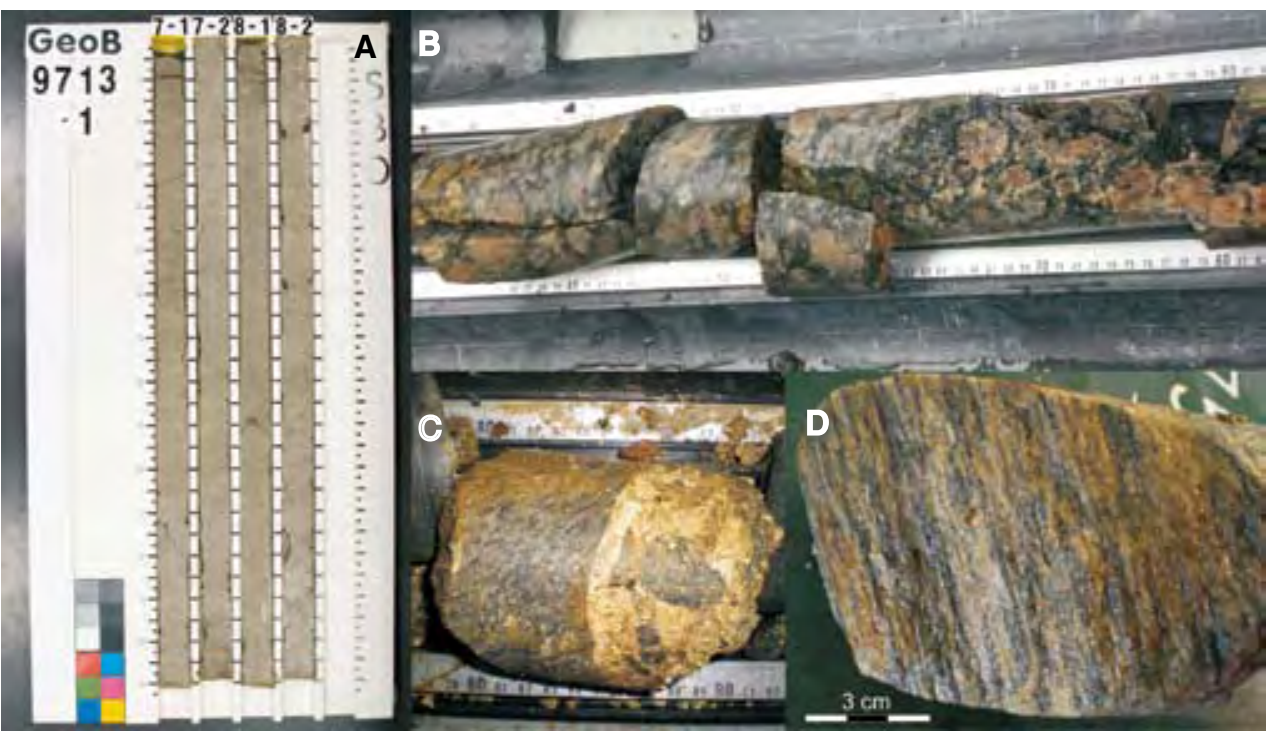

Figure 4. Examples of sea floor samples recovered with the sea floor drill rig MeBo. [A] consolidated pliocene marl, continental slope off Morocco; [B] granite, Porcupine Bank; [C] conglomerate, Porcupine Bank; [D] gneiss, Porcupine Bank.

core were recovered (Fig. 4). The recovery rate was especially good for hard rocks and consolidated cohesive sediments.

\section{Scientific Results of MSM04/4}

In March 2007 the MeBo was deployed for the first time for paleoclimate research on the research vessel Maria $S$. Merian at the continental slope off Morocco (Fig. 5) with two major goals:

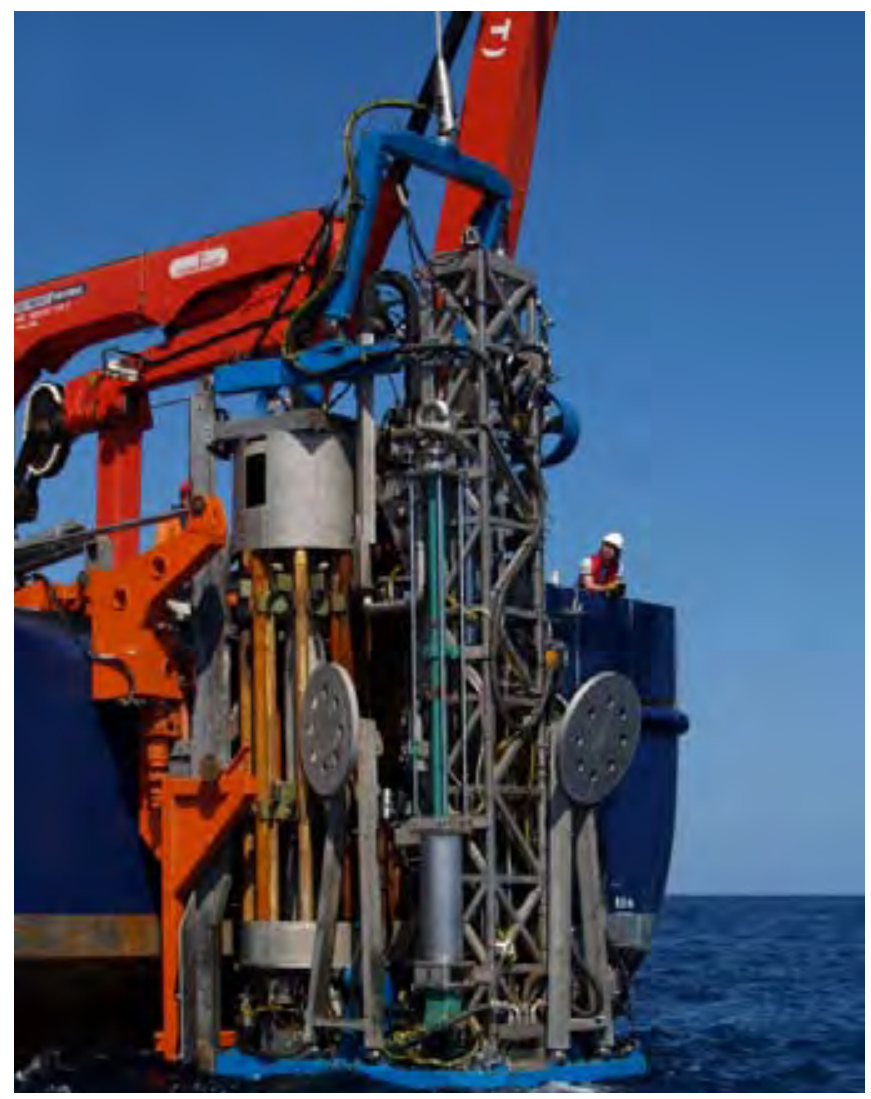

Figure 5. Launch of the sea floor drill rig MeBo from the Maria S. Merian.
1) Two sites with extremely high sedimentation rates of more than $80 \mathrm{~cm} \mathrm{kyr}^{-1}$ were cored for high resolution records of abrupt climate changes during the last glacial period.

2) Two other sites were drilled at and near the former DSDP drilling site 369. A big slide at this part of the continental slope of Morocco allowed for direct sampling of sediments of Miocene age by shallow drilling.

Altogether we recovered approximately 154 meters of sediments at these four sites with a maximum drilling depth of $41.55 \mathrm{~m}$ and about $120 \mathrm{~m}$ core recovery. A highlight at the last drilling site was to recover within forty-eight hours a nearly 40-m-long sediment core of middle to late Miocene age, according to first shipboard nannofossil stratigraphy (Fig. 6). This time period is of special interest for paleoclimate research because it comprises large changes in carbon burial in deep-sea sediments as well as a major step in the formation of the East Antarctic continental ice shield (Vincent and Berger, 1985; Holbourne et al., 2005). Core recovery rate at this site (1720 $\mathrm{m}$ water depth) by rotary drilling with hard metal bits was about $100 \%$. Without the services of the MeBo, it wouldn't have been possible to sample these Miocene consolidated marls from a standard research vessel like RV Maria S. Merian.

\section{Outlook}

With the development of the MeBo system, a substantial improvement of the sampling possibilities for the marine geosciences was achieved. For shallow drilling and coring, the MeBo provides a new and cost effective alternative to the services of drill ships. Worldwide, it is the only system available for marine geosciences that can reach drilling depths of up to $50 \mathrm{~m}$ from standard research vessels. MeBo also has the major advantage that the drilling operations are performed from a stable platform independent of any ship movements caused by waves, wind, or currents. Currently, 


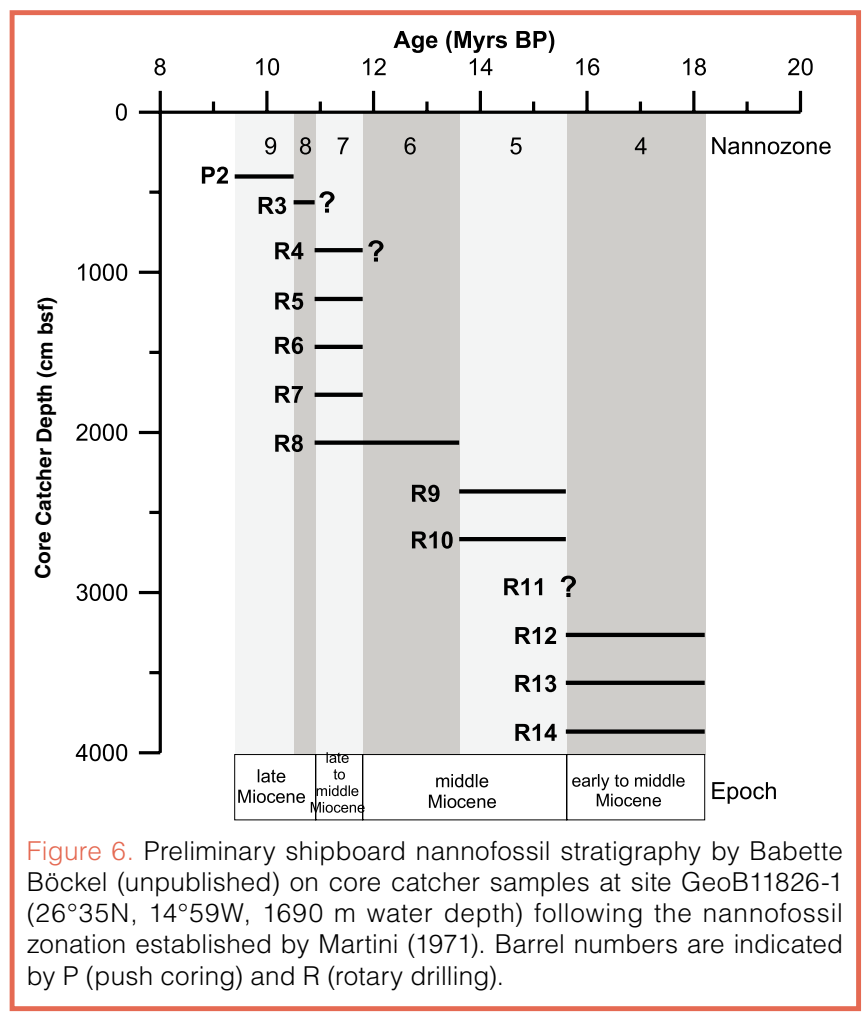

we are working together with Prakla Bohrtechnik GmbH to upgrade the system to use wire-line coring system, which will accelerate the drilling procedure and allow the deployment of logging tools for in-hole data logging. Further plans include the development of a pressure core barrel for the recovery of sediments enriched in gas under in situ pressure conditions, as well as the development of sensor strings to be deployed with the MeBo for long-term monitoring of hydraulic processes and heat flow in the sea floor.

\section{Acknowledgements}

The development of the MeBo was funded by the German Federal Ministry of Education and Research and by the State Government of Bremen. The technicians and engineers at the Marum Center and cooperating companies accomplished an extraordinary performance in getting the MeBo-system running within a short development time. We thank the Leitstelle Meteor/Merian and the Irish Marine Institute for their expedition support and the crews of $R / V$ Meteor, $R / V$ Celtic Explorer and $R / V$ Maria $S$. Merian for their support during the various deployments of the MeBo. The German Research Foundation (DFG) and the DFG Research Center Ocean Margins (RCOM) supported MeBo-cruises M65/3, CE0511, and MSM04/4. We thank the Irish Shelf Petrol Studies Group of the Irish Petroleum Infrastructure Programme Group 4 (comprising Chevron Upstream Europe, ENI Irelandd BV, Island Oil \& Gas plc, Lundin Exploration BV,, Providene Resources plc, Ramco Energy plc, Shell E\&P Ireland Ltd, Statoil Exploration (Ireland) Ltd, Total E\&P UK plc and the Petroleum Affairs Division of the Department of Communications, Marine and Natural Resources) for their faith in the MeBo system, for being the first scientific user of the MeBo, and for financing its deployment on the Porcupine Bank (CE0619).

\section{References}

Freudenthal, T., and Wefer, G., 2006. The sea-floor drill rig "MeBo": robotic retrieval of marine sediment cores. PAGES News, 14(1):10.

Herzig, P.M., Petersen, S., Kuhn, T., Hannington, M.D., Gemmell, J.B., Skinner, A.C., and SO-166 Shipboard Scientific and Technical Party, 2003. Shallow drilling of seafloor hydrothermal systems using R/V Sonne and the BGS Rockdrill: Conical Seamount (New Ireland Fore-Arc) and Pacmanus (Eastern Manus Basin), Papua New Guinea. InterRidge News, 12(1):22-26.

Holbourne, A., Kuhnt, W., Schulz, M., and Erlenkeuser, H., 2005. Impacts of orbital forcing and atmospheric carbon dioxide on Miocene ice-sheet expansion. Nature, 438:483-487, doi:10.1038/nature04123.

Johnson, H.P., 1991. Next generation of seafloor samplers. EOS, 72(7):65-67, doi:10.1029/90EO00045.

Martini, E., 1971. Standard Tertiary and Quaternary calcareous nannoplankton zonation, In Farinaci, A. (Ed.), Proceedings of the Second Planktonic Conference Roma 1970, Rome (Edizioni Tecnoscienza), 739-785.

Quinn, T.M., and Mountain, G.S., 2000. Shallow water science and ocean drilling face challenges. EOS, 81(35):397-400, doi:10.1029/00EO00293.

Sager, W., Dick, H., Fryer, P., and Johnson, H.P., 2003. Report from a workshop. Requirements for robotic underwater drills in U.S. marine geologic research., Texas A\&M University, College Station, Texas, 3-4 November 2000. http://www. usssp-iodp.org/PDFs/DrillRep51403.pdf.

Stuart, S., 2004. The remote robot alternative. Intl. Ocean Syst., $8(1): 23-25$.

Vincent, E., and Berger, W.H., 1985. Carbon dioxide and polar cooling in the Miocene: The Monterey hypothesis. In Sundquist, E.T., and Broecker, W.S. (Eds.), The carbon cycle and atmospheric CO2: natural variations Archean to present, $A G U$ Geophysical Monographs 32, 455-468.

Wefer, G., Bergenthal, M., Buhmann, S., Diekamp, V., Düßmann, R., Engemann, G., Freudenthal, T., Hemsing, V., Hill, H.-G., Kalweit, H., Klar, S., Könnecker, H.-O., Lunk, T., Renken, J., Rosiak, U., Schmidt, W., Truscheit, T., and Warnke, K., 2006. Report and preliminary results of $R / V$ METEOR cruise M65/3, Las Palmas - Las Palmas (Spain) 31 July10 August 2005, Berichte, Fachbereich Geowissenschaften, Universität Bremen, 254: 24p.

\section{Authors}

Tim Freudenthal, Marum Center for Marine Environmental Sciences, University of Bremen, Leobener Str. D-28359 Bremen, Germany, e-mail: freuden@marum.de.

Gerold Wefer, Marum Center for Marine Environmental Sciences, University of Bremen, Leobener Str. D-28359 Bremen, Germany.

\section{Related Web Link}

http://www.rcom.marum.de/English/Sea_floor_drill_rig_ MeBo.html 